\title{
Biogeography of marine bivalve mollusks of eastern Korea
}

\author{
Konstantin A. Lutaenko and Ronald G. Noseworthy \\ A.V. Zhirmunsky Institute of Marine Biology, Far Eastern Branch of the Russian Academy of Sciences, Vladivostok 690041, \\ Russia \\ Faculty of Marine Biomedical Sciences, Jeju National University, Jeju-si 690-756, Republic of Korea
}

\begin{abstract}
The biogeography and diversity patterns of the marine bivalve molluscan fauna of the East Sea coast of South Korea are analyzed. The total species richness of the continental Korean bivalve fauna, excluding insular regions (Dok-do and Ullung-do), is 304, and from north to south the species richness of bivalves increases showing a clear gradient: Gangwon, 143 species $\rightarrow$ Gyeongbuk, $131 \rightarrow$ Gyeongnam, 183. A zonal-geographical analysis of the entire fauna shows that the great majority are warm-water mollusks, constituting $77 \%$ (subtropical, $37 \%$, tropical-subtropical, 30\%, subtropical-boreal, 10\%), The number of boreal (low-boreal, widely distributed boreal and circumboreal) species is lower, $19 \%$, whereas boreal-arctic mollusks have only $4 \%$. This demonstrates that the bivalve molluscan fauna of the eastern coast of Korea is subtropical, and has more affinities to the fauna of the East China Sea than to the northern East Sea. Separate analysis by provinces shows the increasing role of warm-water mollusks from north to south. While tropical-subtropical and subtropical species constitute $47 \%(68$ species) in Gangwon, their dominance increases to $71 \%$ (93 species) in Gyeongbuk, and to $80 \%$ (148 species) in Gyeongnam. The Gyeongnam bivalve fauna is the most diverse in species composition and has the largest number of "endemics" (species known only from this province), $46 \%$. The Gangwon fauna also contains many "endemics", up to $40 \%$, while Gyeongbuk is an intermediate zone with low "endemicity", only at one-fifth of the regional fauna, and has the most species in common among the three provinces.
\end{abstract}

Key words: bivalve mollusks, species richness, biogeography, zonation, Korea, East Sea

\section{INTRODUCTION}

The bivalve molluscan fauna of the East Sea (Sea of Japan) has been studied rather comprehensively up to the present but no inventory for the entire sea has appeared. The Korean fauna has received much attention during the last twenty years (Lee and Min, 2002; Min et al., 2004; Noseworthy et al., 2007). Recently, we published a catalogue of the bivalves of the western part of the sea, from Busan in the south

Received: September 20, 2014; Revised: September 22, 2014; Accepted: September 25, 2014

Corresponding author : Konstantin A. Lutaenko

Tel: +7 (423) 2317-111 e-mail: lutaenko@mail.ru

$1225-3480 / 24539$

This is an Open Access article distributed under the terms of the Creative Commons Attribution Non-Commercial License with permits unrestricted non-commercial use, distribution, and reproducibility in any medium, provided the original work is properly cited. to Tatarsky Strait in the north (Lutaenko and Noseworthy, 2012) summarizing for the first time all distributional data on the bivalves of the Korean and Russian areas of the sea, and showing regional distribution of species in South Korea by provinces, from south to north: South Gyeongsang Province, Gyeongsangnam-do (short form - Gyeongnam), North Gyeongsang Province, Gyeongsangbuk-do (Gyeongbuk), and Gangwon Province, Gangwon-do (Gangwon) (Fig. 1). Gangwon Province is divided between North and South Korea. This paper analyzes the bivalve mollusk diversity and biogeographical patterns on the East Sea side of South Korea based on this catalogue. Some preliminary results of biogeographical analyses of the western East Sea bivalve fauna were presented at a number of the Chinese-Russian marine biology meetings (Lutaenko, 2010, 2012), and a more detailed zoogeographical treatment was published recently (Lutaenko and Noseworthy, 2014) but the latter paper 


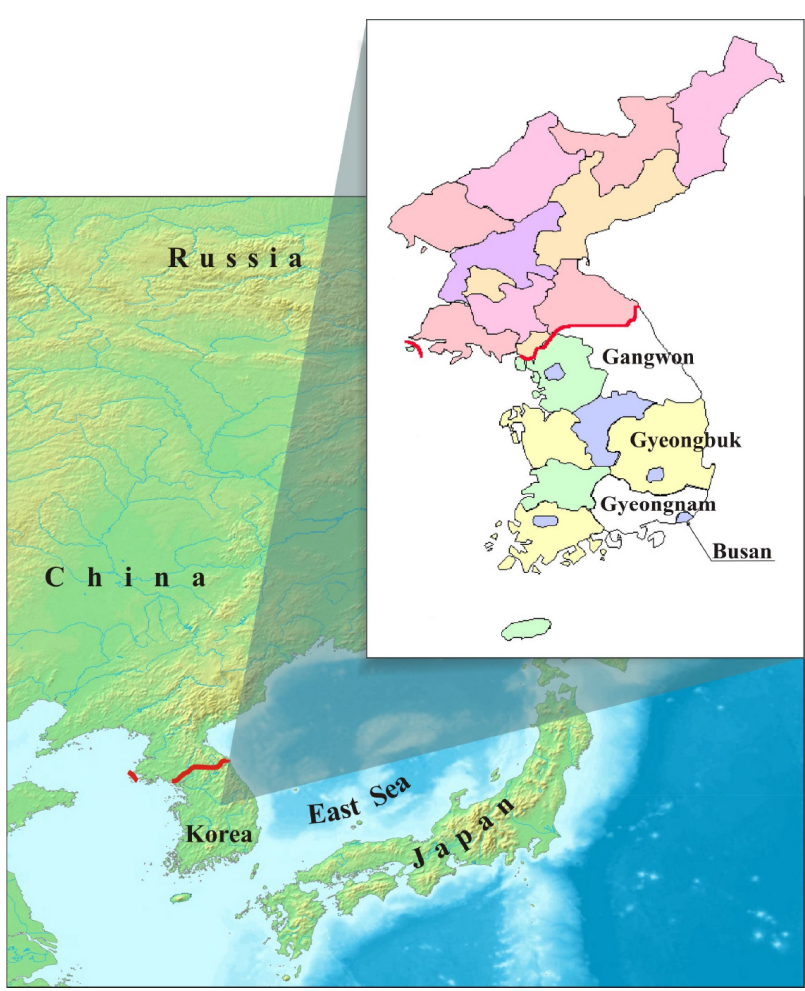

Fig. 1. A map of the East Sea and Korea showing the provinces along the eastern coast: Gyeongnam (Gyeongsangnam-do), Gyeongbuk (Gyeongsangbuk-do), Gangwon (Gangwond-do).

did not consider regional differences in biogeography within South Korean waters.

\section{SPECIES RICHNESS}

According to the catalogue (Lutaenko and Noseworthy, 2012), the bivalve molluscan fauna of eastern South Korea included 312 species. Since publication of the catalogue, new records for this region became known: Carditellopsis toneana (Yokoyama, 1922) (Carditidae) and Fulvia hungerfordi (G.B. Sowerby III, 1901) (Cardiidae) are new records for the East Sea coast of Korea, and Crenella decussata (Montagu, 1808) (Mytilidae) is a new record for Korea, all collected from Ulsan Bay (Lutaenko, 2014). Laternula boschasina (Reeve, 1860) (Laternulidae) was known for Ulsan Bay (Yi et al., 1982) but it was missed in the catalogue. Also, new provincial records are added to the catalogue: Yoldia notabilis Yokoyama, 1922, Axinopsida subquadrata (A. Adams, 1862), Salaputium cf. unicum Hayami et Kase,
1993, Nipponomysella oblongata (Yokoyama, 1922), Callista brevisiphonata (Carpenter, 1864), and Dosinia penicillata (Reeve, 1850) (all from Ulsan (Lutaenko (2014)). Tucetonella munda (Sowerby III, 1903) and Callista chinensis (Holten 1803) (illustrated for Busan in Lutaenko and Noseworthy (2012)); and Anomia chinensis Philippi, 1849 (Ulsan: Rho et al. (1997)) are new for Gyeongnam. Glycymeris imperialis Kuroda, 1934 and Solecurtus divaricatus (Lischke, 1869) (found near Uljin by K. Lutaenko, July 2012) are new records for Gyeongbuk although all these species were previously known from other provinces.

Thus, in total, 316 species of Bivalvia are known currently for the East Sea coast of South Korea (south to Busan). However, this figure includes species of bivalves not only from the continental area of South Korea itself, but also known from insular regions of Korea, namely, Dok-do (Liancourt Rocks) and Ullung-do (Dagelet Island), lying far away from the continent. We believe that these faunas are distinct in terms of their composition, relationships with the continental fauna, and biogeographic patterns. Dok-do is located at a distance of $216 \mathrm{~km}$ from mainland Korea, and consists of two large volcanic islands and 89 small islets, whereas Ullung-do is located at a distance of $87 \mathrm{~km}$ from Dok-do and $120 \mathrm{~km}$ from the Korean Peninsula. The influence of the warm East Korean Current is conducive to the spreading of warm-water species into these areas, so the fauna of Ullung-do and Dok-do should be more subtropical than that of mainland Korea at the same latitude. Recent data show that tropical-subtropical chamids (Chamidae) are represented by six species in Dok-do (Ryu et al., 2012), whereas only three chamid species are known from the eastern coast of Korea (Lutaenko and Noseworthy, 2012). Therefore, data on Dok-do and Ullung-do are not taken into account in our analysis of the biogeography of the three eastern Korean provinces.

Excluding species found only in the two insular areas and species identified only to genus level, the total species richness of the continental Korean bivalve fauna is 304. Among them, exact distribution (by provinces) of 10 species (Solamen columbianum (Dall, 


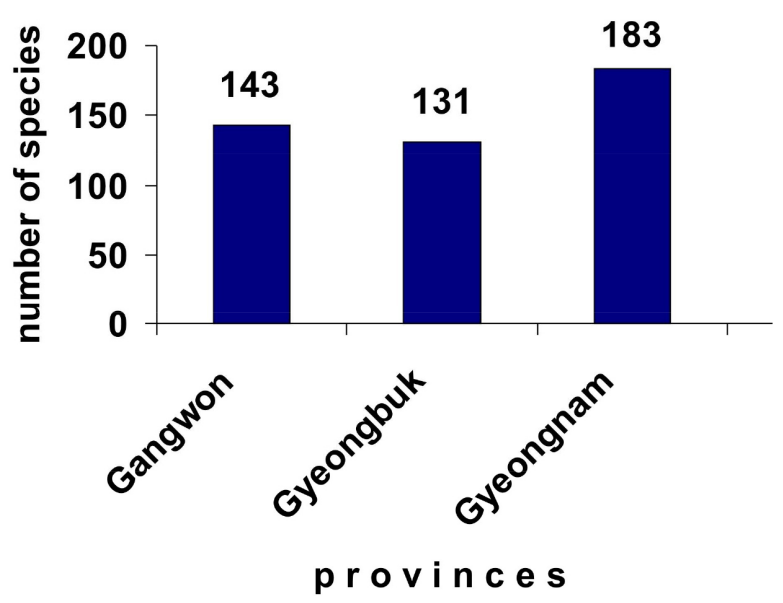

Fig. 2. Species richness of bivalve mollusks along the continental coast of East Sea of Korea (from north to south); for location of provinces, see Fig. 1.

1897), Pinctada albina (Lamarck, 1819), Pododesmus umbonata (Gould, 1861), Amusium japonicum (Gmelin, 1791), Lucinoma yoshidai Habe, 1958, Miodontiscus annakensis (Oinomikado, 1938), Acrosterigma burchardi (Dunker, 1877), Meiocardia samarangiae Bernard, Cai et Morton, 1993, Cycladicama coreensis (Adams et Reeve, 1850), and Solen gordonis Yokoyama, 1920) are not known although they are recorded from East Sea coast based on various literature sources (Lutaenko and Noseworthy, 2012). In case of these species, the literature gives simply a distribution range, such as "east coast", or "south-east coast".

The species richness of bivalves along the entire western shore of the East Sea shows a clear latitudinal gradient from north to south (Lutaenko and Noseworthy, 2014). In Russia, 130 species are known for middle and northern Primorye, the area of the continental coast of the sea from Cape Povorotny to Tatarsky Strait, and 158 species for southern Primorye (Peter the Great Bay); in South Korea, 316. North Korean waters are poorly studied, and only 66 species are known at present (Lutaenko and Noseworthy, 2012; Lutaenko and Pretsiniek, 2014). Along the South Korean coast, from north to south, species richness of bivalves also increases: Gangwon, 143 species $\rightarrow$ Gyeongbuk, $131 \rightarrow$ Gyeongnam, 183 (Fig. 2). This gradient is a fundamental pattern of ecology and biogeography: the increase in biological diversity from polar to equatorial regions (Willig et al., 2003).

A comparison of the bivalve molluscan fauna of South Korea with neighboring areas shows that the fauna is quite rich, and is comparable with that of the East China Sea, which has 337 species (Xu and Zhang,

Table 1. Species richness of bivalve molluscan faunas in the East Sea large localities and adjacent areas

\begin{tabular}{ccc}
\hline Locality & Species richness & Reference \\
\hline Japan & 1472 & Higo et al. (1999) \\
Wakasa Bay (Honshu) & 207 & Ito (1990) \\
$\begin{array}{c}\text { Ichikawa Prefecture } \\
\text { (includes Noto Peninsula) }\end{array}$ & 119 & Ito et al. (1986) \\
Sado Island & 211 & Kuroda (1957); \\
Korea & 449 & Honma, Kitami (1978, 1979, 1995) \\
Lee and Min (2002)
\end{tabular}


Biogeography of marine bivalve mollusks of eastern Korea

Table 2. Number of "endemic" (confined to a specific province) bivalve species in regional faunas of South Korea

\begin{tabular}{ccccc}
\hline Province & $\begin{array}{c}\text { Total number of } \\
\text { species found }\end{array}$ & $\begin{array}{c}\text { Number of "endemic" } \\
\text { species (not known } \\
\text { in other provinces) }\end{array}$ & $\begin{array}{c}\text { Proportion of "endemic" to } \\
\text { total number of species } \\
\text { found in South Korea } \\
\text { (with known regional } \\
\text { distribution - 304) }\end{array}$ & $\begin{array}{c}\text { Proportion of } \\
\text { "endemic" to total } \\
\text { number of species } \\
\text { found in a specific } \\
\text { province }\end{array}$ \\
\hline Gangwon & 143 & 57 & $19 \%$ & $40 \%$ \\
Gyeongbuk & 131 & 26 & $8.5 \%$ & $20 \%$ \\
Gyeongnam & 183 & 84 & $28 \%$ & $46 \%$ \\
\hline
\end{tabular}

2011) (Table 1). In all South Korea, 449 species are known (Lee and Min, 2002), whereas the faunas of China and Japan are richer - 1104 and 1472 species, respectively (Higo et al., 1999; Xu and Zhang, 2011). However, species richness of bivalves of the East Sea coast of Korea is close to those of the entire temperate North-Western Pacific (Table 1) which can be explained by the influence of subtropical waters in the south-eastern part of the Korean Peninsula.

Although latitudinal gradients in coastal faunas show a poleward decline in richness, they are irregular both within and among regions (Rex et al., 2005). For instance, species richness is rather high along the eastern (Japanese) coast of the East Sea; Wakasa Bay and Sado Island bivalve faunas exhibit species richness (207-211 species) similar to those of southerly-located Jeju Island (225) (Table 1). The northern part of the East Sea (Russian sector) (130-158 species) is poorer in bivalves than the South Korean coast, but the former region is closer in species richness to the impoverished Yellow Sea (175 species).

\section{REGIONAL DIFFERENCES IN SPECIES COMPOSITION}

As we have shown in a previous section, there are obvious differences in species richness of bivalve faunas along the eastern coast of Korea related to latitude and thus to temperature gradient. Therefore, species compositions should be different too. We calculated the proportions of "endemic" species, i.e., confined to a specific province and not found in other provinces along the eastern coast of Korea, in both the entire fauna and in each province's fauna, and the figures obtained appear surprisingly high.

The Gyeongnam bivalve fauna has the highest number of "endemic" species - 84, which constitutes nearly half of the province's species list (46\%), or $28 \%$ of the total eastern South Korean fauna (Table 2). This clearly indicates that nearly one-third of bivalves inhabiting eastern Korea are found in only its most southern part, Gyeongnam, and a majority of them are warm-water, tropical-subtropical and subtropical, species. The representativies of six truly tropical families, Pteriidae, Pinnidae, Dimyidae, Glauconomidae, Glossidae, Mesodesmatidae, and mostly tropical genera Striarca (Noetiidae), Gregariella (Mytilidae), Lucinoma, Wallucina, Gonimyrtea, Divalucina (Lucinidae), Trapezium (Trapezidae), Carditellopsis (Carditidae), Microcardium, Keenaea (Cardiidae), Chama (Chamidae), Lutraria (Mactridae), Pharaonella, Loxoglypta, Bathytellina (Tellinidae), Abra (Semelidae), Azorinus (Solecurtidae), Antigona, Timoclea, Pitar, Paphia, Cyclosunetta, Meretrix, Claudiconcha (Veneridae), and Venatomya (Myidae) are recorded only from Gyeongnam. This biogeographical pattern, the concentration of warm-water mollusks in the southernmost part of eastern Korea, is governed by the influence of warm currents and the generally nearly-subtropical conditions of shallow waters. The warm Tsushima Current and South Korean Coastal Current (SKCC) are dominant in this area of coastal Korea: the Tsushima comes from the south and flows through the South Sea toward the East Sea, and the SKCC flows northeastward along the southern coastline. An additional, but important, factor contributing to the 
thriving of tropical and subtropical mollusks is the strongly indented coastline with headlands, bays, and islands in south-eastern Korea. The length of this coastline is nearly eight times longer than its straight-line distance, and its indentation is far greater than that of the west coast (Kwon and Lee, 2010). The tidal range here is from two to five meters, and tidal flats are not as extensive as along the west coast (l.c.) but this coastal topography provides habitat and shelter to numerous intertidal, tropical-subtropical bivalves, thus increasing the variety of substrata and environments.

In Gyeongbuk, only $20 \%$ of the total provincial fauna is "endemic" which comprises only $8.5 \%$ of the total Korean East Sea fauna. In Gyeongbuk Province only, warm-water Indocrassatella (Crassatellidae), Coralliophaga (Trapezidae), Pseudochama (Chamidae), Petricola, Petricolirus (Veneridae), Paramya (Myidae), Uperotus (Teredinidae), Gastrochaena (Gastrochaenidae), Myadoropsis (Myochamidae), Bentholyonsia (Lyonsiidae) are found. We expect that their distribution can be extended to Gyeongnam region when more data are available.

The Gangwon fauna has a rather high proportion of species found only in this province, and are not known southward: 57 , or $40 \%$ of the total provincial fauna (Table 2). However, opposite to Gyeongnam, "endemics" are predominantly boreal species, widely distributed boreal, circumboreal, and lowboreal, with an admixture of some warm-water mollusks. Gangwon is very rich in cold water families; Nuculanidae and Yoldiidae, are well represented within Korean East Sea waters, mostly in Gangwon. Of the 15 Korean species, a majority, 13 species, are found only in Gangwon waters. Such mainly boreal genera as Robaia (Nuculanidae), Portlandia, Megayoldia (Yoldiidae), Musculus, Dacrydium (Mytilidae), Parvamussium (Propeamussiidae), Serripes (Cardiidae), Mactromeris (Mactridae), Liocyma, Turtonia (Veneridae), Bankia (Teredinidae), Panomya (Hiatellidae), Thracia (Thraciidae) are recorded only from Gangwon. They are rather deep-water faunal elements inhabiting mainly the lower subtidal zone in the northern East Sea although they may live in shallow waters in high latitudes. Only two families, Nuculanidae and Thraciidae, are found exclusively in Gangwon, on the East Sea coast of South Korea.

Gyeongbuk plays the role of an intermediate faunal region between the boreal and cold-water species of Gangwon and the obviously subtropical Gyeongnam. In fact, the limits of the distributional ranges of such typical northern East Sea shallow boreal and subtropical-lowboreal bivalves as Glycymeris yessoensis (Sowerby III, 1889), Crenomytilus grayanus (Dunker, 1853), Adula schmidtii (Schrenck, 1867), Chlamys swiftii (Bernardi, 1858), Mizuhopecten yessoensis (Jay, 1857), Clinocardium ciliatum (Fabricius, 1780), C. californiense (Deshayes, 1839), Spisula sachalinensis (Schrenck, 1861), Cadella lubrica (Gould, 1861), Gari kazusensis (Yokoyama, 1922), and Mercenaria stimpsoni (Gould, 1861) (Fig. 3) lie in Gyeongbuk, and they usually do not form dense populations in South Korea as compared to the north-western East Sea (Golikov and Scarlato, 1967; Scarlato, 1981; Kolpakov and Kolpakov, 2004; Lutaenko, 2006; Sedova et al., 2007; Sedova and Sokolenko, 2008). Some of these species, such as $G$. yessoensis and $C$. californiense extend to the Yellow Sea, and they exist there as relics of the Quaternary coolings along with true cold-water species whose populations are often separated from the northern populations in the East Sea (Amano, 2005).

In other words, the Gyeongnam bivalve fauna is the most "original" in species composition along the continental coast of South Korea as it has the highest number of "endemics", or species known only from this province. The Gangwon Province fauna also contains many species living only in this region, up to $40 \%$ of the total fauna; Gyeongbuk is an intermediate zone with low "endemicity", only one-fifth of the regional fauna, and the latter fauna has the most species in common among three provinces. The difference is that "endemic" species in each province are of an opposite nature - mostly boreal and cold-water in the north, and tropical-subtropical and subtropical in the south. Distributional ranges of typical boreal species, dominating benthic communities in the northern East Sea, extend down to Gyeongbuk Province, whereas 


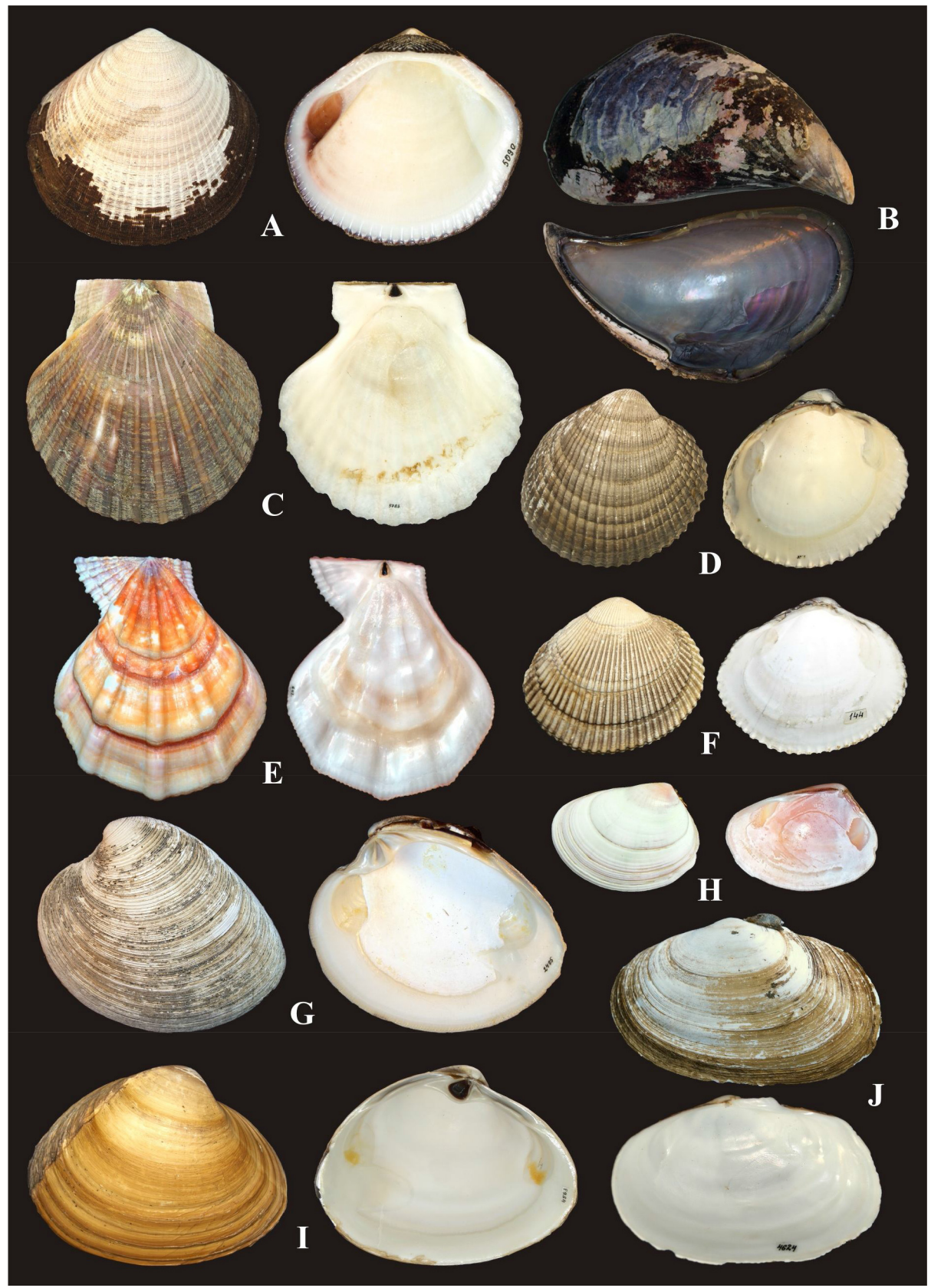

Fig. 3. Boreal bivalve mollusks dominating in shallow-water bottom communities of the northern East Sea whose limits of distributional ranges extend to Gyeonbuk Province: A - Glycymeris yessoensis (Sowerby III, 1889) (East Sea, Peter the Great Bay, shell length $54.4 \mathrm{~mm}$, ZMFU 32989/Bv-5090); B - Crenomytilus grayanus (Dunker, 1853) (East Sea, Peter the Great Bay, shell length 82.7 mm, ZMFU 28554/Bv-4861); C - Mizuhopecten yessoensis (Jay, 1857) (East Sea, North Korea, Chongjin, shell length 65.9 mm, ZMFU no. 38377/Bv-5783); D - Clinocardium ciliatum (Fabricius, 1780) (East Sea, Peter the Great Bay, shell length $70 \mathrm{~mm}$, ZMFU 20950/Bv-3381); E - Chlamys swiftii (Bernardi, 1858) (East Sea, Peter the Great Bay, shell length 90.6 mm, ZMFU 10258/Bv-647); F - Clinocardium californiense (Deshayes, 1839) (East Sea, Peter the Great Bay, shell length $58.7 \mathrm{~mm}$, ZMFU 9148/Bv-144); G - Mercenaria stimpsoni (Gould, 1861) (East Sea, Possjet Bay, shell length 83.6 mm, ZMFU 18144/Bv-2495); H - Cadella lubrica (Gould, 1861) (East Sea, Peter the Great Bay, shell length $15.5 \mathrm{~mm}$, ZMFU 9340/Bv-236); I - Spisula sachalinensis (Schrenck, 1861) (East Sea, Possjet Bay, shell length 103.8 mm, ZMFU 27495/Bv-4563); J - Gari kazusensis (Yokoyama, 1922) (East Sea, Peter the Great Bay, shell length 53.5 mm, ZMFU 19372/Bv-2843). 
more deep-water (lower subtidal) elements of the northern fauna inhabit mostly the Gangwon region.

\section{ZONAL-BIOGEOGRAPHICAL ANALYSIS}

In our analysis of the biogeographical structure of the bivalve molluscan faunas of three provinces of South Korea along the western East Sea, we follow the zonal-geographical (zonal-biogeographical) approach. In this methodology, the temperate waters and fauna of the northern hemisphere are called boreal (Kussakin, 1990), and the term "boreal" corresponds to the American terms "cold-temperate" or "cool-temperate" (e.g., Hall, 1964; Briggs, 1974). The boreal zone is divided into "high-boreal" and "low-boreal" (sometimes "north-boreal" and "south-boreal"). The term "warm-temperate" of American workers should correspond to "subtropical". We recognize six major zonal-geographical groups: 1. tropical-subtropical (distributed southward to the Philippines, Vietnam, and Indonesia); 2. subtropical (distributed southward to Taiwan and the northern part of the South China Sea); 3. subtropical-lowboreal (limited both to subtropical seas and the East Sea, southeastern Sakhalin, and the southern Kuril Islands); 4. lowboreal (limited to the East Sea from Peter the Great Bay, northern Korea, and northern Honshu to Aniva and Terpenya bays, southwestern Sakhalin, and the southern Kurile Islands); 5. widely distributed boreal (limited to the East Sea and Hokkaido to the Bering Strait, along the Asian coast, and along the northern American coast southward to California), and circumboreal (limited mainly to temperate latitudes, both in the Atlantic and Pacific Oceans, but also partly to subtropical and arctic zones); 6. boreal-arctic (limited to both the temperate zone of the Pacific Ocean and the Arctic, and partly to the temperate Atlantic). We checked the geographical distribution of many species using numerous literature sources, and unified zonal-geographical characteristics are given for each species in our catalogue (Lutaenko and Noseworthy, 2012).

We analyzed 304 species of the entire fauna with respect to their zonal-geographical characteristics. Among them, the great majority were warm-water

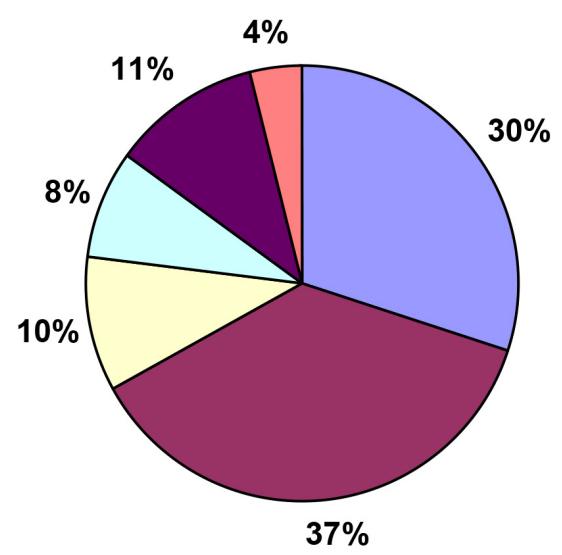

$\square \mathrm{t} / \mathbf{s} \square \mathbf{s} \square \mathbf{s} / \mathbf{b} \square \mathrm{lb} \square \mathbf{w d b} \square \mathrm{b} / \mathbf{a}$

Fig. 4. Zonal-geographical composition of bivalve molluscan fauna of the East Sea coast of South Korea (without Dok-to and Ullung-do): t/s - tropical-subtropical species; s - subtropical; s/b - subtropical-boreal (mainly subtropical-lowboreal) species; lb - lowboreal species; wdb - widely distributed boreal and circumboreal species; b/a - boreal-arctic species.

mollusks, constituting $77 \%$, with subtropical being prevalent at $37 \%$ (112 species) and tropical-subtropical at $30 \%$ (91 species), and the rest are subtropical-boreal (mostly subtropical-lowboreal) species (30, or $10 \%)$. The number of boreal (low-boreal, widely distributed boreal and circumboreal) species is lower, only 19\% (57 species). Boreal-arctic mollusks are also present with 14 species, or $4 \%$ (Fig. 4). These proportions are close to a combined analysis of coastal and insular faunas made earlier (Lutaenko and Noseworthy, 2014), and demonstrate that the bivalve molluscan fauna of the eastern coast of Korea is subtropical, and has more affinities to the fauna of the East China Sea than to the northern East Sea (e.g., Russian part).

A separate analysis of zonal-geographical compositions by provinces (Figs. 5-7) demonstrates a well-manifested trend of the increasing proportion of warm-water mollusks from north to south. While tropical-subtropical and subtropical species constitute 47\% (68 species) in Gangwon, their dominance increases to $71 \%$ (93 species) in Gyeongbuk, and to 80\% (148 species) in Gyeongnam (Fig. 8). However, the 


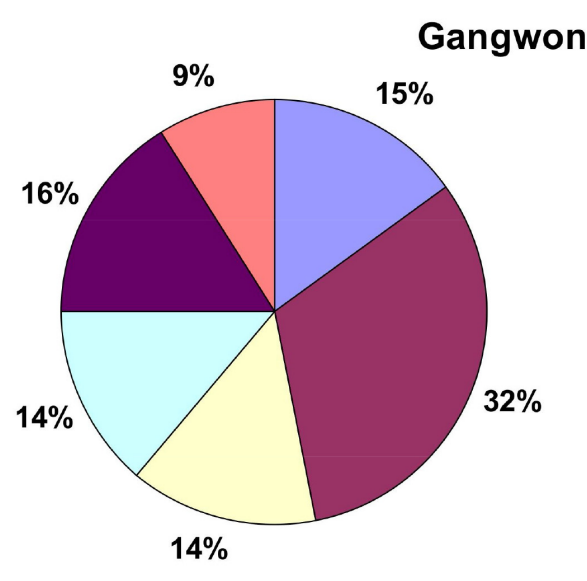

$\square \mathrm{t} / \mathbf{s} \square \mathrm{s} \square \mathbf{s} / \mathbf{b} \square \mathrm{lb} \square \mathrm{wdb} \square \mathrm{b} / \mathrm{a}$

Fig. 5. Zonal-geographical composition of bivalve molluscan fauna of Gangwon Province of South Korea. For explanations, see caption to Fig. 4.

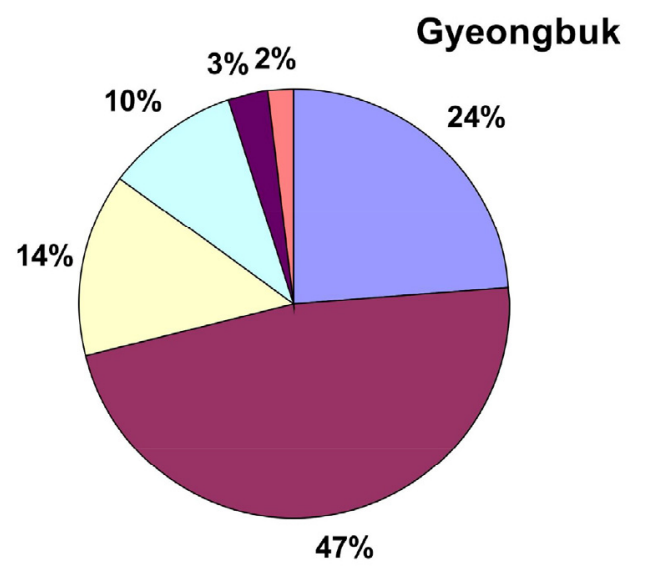

$$
\square \mathrm{t} / \mathrm{s} \square \mathrm{s} \square \mathrm{s} / \mathrm{b} \square \mathrm{lb} \square \mathrm{wdb} \square \mathrm{b} / \mathrm{a}
$$

Fig. 6. Zonal-geographical composition of bivalve molluscan fauna of Gyeongbuk Province of South Korea. For explanations, see caption to Fig. 4.

relative proportion and number of subtropicallowboreal species (with a few more broadly distributed subtropical-boreal, e.g., Mytilus galloprovincialis Lamarck, 1819, Modiolus kurilensis Bernard, 1983) remain about the same throughout the coast: Gangwon, 20 species (14\%) $\rightarrow$ Gyeongbuk, $18(14 \%) \rightarrow$ Gyeongnam, 19 (10\%).

The species richness of truly boreal, lowboreal,

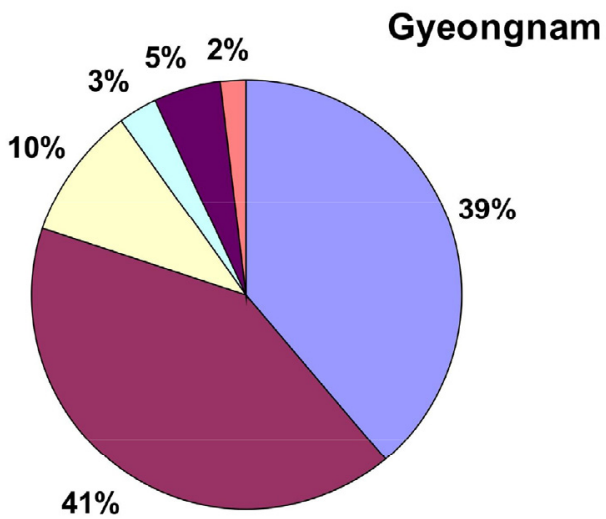

$\square \mathrm{t} / \mathrm{s} \square \mathrm{s} \square \mathrm{s} / \mathrm{b} \square \mathrm{lb} \square \mathrm{wdb} \square \mathrm{b} / \mathrm{a}$

Fig. 7. Zonal-geographical composition of bivalve molluscan fauna of Gyeongnam Province of South Korea. For explanations, see caption to Fig. 4.

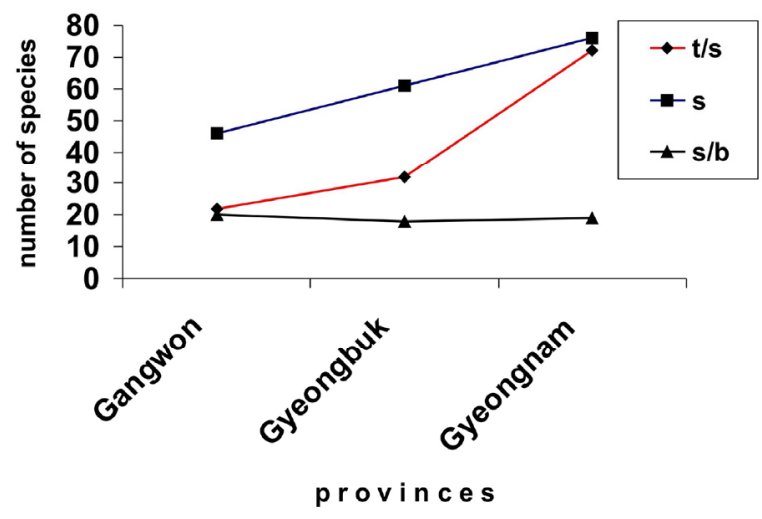

Fig. 8. Changes in number of species of warm-water bivalve mollusks along the eastern coast of South Korea (t/s tropical-subtropical species, s - subtropical species, s/b - subtropical-boreal (mostly subtropical-lowboreal) species).

widely distributed boreal, and circumboreal, bivalves also shows a clear gradient from north to south along the continental coast of the East Sea of Korea (Fig. 9): Gangwon, 43 species (30\%) $\rightarrow$ Gyeongbuk, $17(13 \%) \rightarrow$ Gyeongnam, 13 (8\%). Their relative role in those faunas becomes insignificant in the south, whereas they constitute nearly one-third of the fauna in the north. An abrupt, four-fold change reveals boreal-arctic mollusks represented by 12 (9\%) species in Gangwon, and only by three species (2\%) in each of the southern 


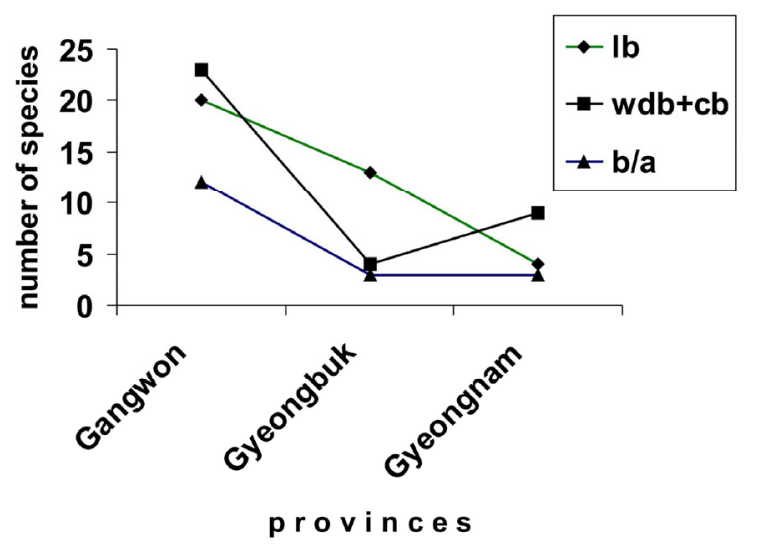

Fig. 9. Changes in number of species of boreal (lb low-boreal, wdb + cb - widely distributed boreal and circumboreal species) and boreal-arctic (b/a) bivalve mollusks along the eastern coast of South Korea.

provinces (Fig. 9).

Comparing the trends of change in zonalbiogeographical compositions of larger faunas along the western coast of the East Sea, both Russian and Korean, we can speculate that the main pattern from north to south can be described as the significant enrichment of the southern part of the sea, the total South Korean fauna, by subtropical and tropical-subtropical faunal elements. Boreal species occur in both faunas in rather similar proportions (Lutaenko and Noseworthy, 2014); the main pattern within the South Korean fauna is similar for warm-water species - more than a two-times increase, but the boreal mollusks show a clear gradient and their number decreases three times. This pattern is again explained by the influence of warm currents and overall warm, shallow water conditions due to latitude.

Unfortunately, bathymetric data on bivalve distribution in South Korean waters are not detailed, and we cannot perform a thorough analysis of zonal-biogeographical complexes related to depth. Zonal-geographical composition of the fauna changes with depth, and the bathymetric distribution of biogeographical complexes in the North-Western Pacific shows that warm-water species prefer the upper subtidal zone while cold-water species concentrate deeper (Scarlato, 1981). For instance, in the north-western East Sea, an overwhelming majority of subtropical and subtropical-lowboreal mollusks inhabits the depth range of $0-30 \mathrm{~m}$ but are rare below $31 \mathrm{~m}$; tropical-subtropical species are not recorded deeper than $61 \mathrm{~m}$. In contrast, the number of boreal-arctic species increases with depth.

Lutaenko et al. (2006) analyzed depth distributions of selected bivalves in Yeongil Bay (Gyeongbuk): considering the upper bathymetric limits of such species as Acila insignis (Gould, 1861) (19.5-35.5 m), Yoldia notabilis Yokoyama, 1922 (8.5-52 m), Felaniella usta (Gould, 1861) (8.5-25 m), Theora lubrica Gould, $1861(8.5-28 \mathrm{~m})$. and some others, they found out that in the northern areas of the East Sea, in Peter the Great Bay, these species inhabit more shallow waters, i.e., they shift their upper limits into upper 1-4 m deep. This might be associated with differential summer heating of coastal waters in Peter the Great Bay and Yeongil Bay. Some embaymental areas in the former bay can warm up to $28^{\circ} \mathrm{C}$, while maximum bottom temperatures in the latter bay in 1973-1978 reached only $19^{\circ} \mathrm{C}$ (Yoo and Park, 1979). Therefore, it appears that warm-water and relatively warm-water (lowboreal) mollusks can extend to the north-western East Sea, while they live more deeply in Yeongil Bay; however, further bathymetric data are needed to prove this conclusion. Warm-water species are found deeper along the Japanese coast of the East Sea due to the warming effect of the Tsushima Current (Lutaenko et al., 2006; Lutaenko, 2014).

The Ulsan Bay (Gyeongnam) bivalve fauna also clearly exhibits wider depth ranges of warm-water bivalves as compared to northern regions of the East Sea which can be explained by the influence of warm currents on the lower subtidal zone of the southern part of the sea. Arca boucardi Jousseaume, 1894 does not live in the northern part of the sea deeper than 18 $\mathrm{m}$ while it is found on the Japan coast as deep as 210 $\mathrm{m}$, and in Ulsan Bay at a depth of $43 \mathrm{~m}$; Dosinia penicillata (Reeve, 1850), a relic of the mid-Holocene warming in Peter the Great Bay, lives there only in semi-enclosed bays and not deeper than $7 \mathrm{~m}$, but it is found at a depth of 22-43 $\mathrm{m}$ in Ulsan Bay (Lutaenko, 2014). This important biogeographic phenomenon can be regarded as the displacement of warm-water species 
into the upper subtidal zone in the high-latitude margin of their range, whereas the occurrence of cold-water species at greater depths in the low-latitude margin of their range, quite common in temperate latitudes, is called "submergence".

\section{FAUNAL ZONATION}

Kafanov (1991) suggested that, along the continental coast of the East Sea, three faunal areas can be recognized: Osaka Province (south of the Busan/Yeongil Bay area), East Korea Province (between Busan and Chongjin in North Korea), and "Northern Sea of Japan District" of the Sakhalin Province (north-western part of the sea - from Chongjin to Tatarsky Strait). The boundaries of his units were mostly defined by an analysis of species richness but this scheme was not well-substantiated because of limited data on the Korean molluscan fauna at that time. Later Kafanov et al. (2000) examined the species richness of fishes, an analysis of latitudinal distribution of 1130 species of fishes, indicating ten local maxima and minima, in the East Sea. He proposed a new scheme of faunistic zoning, and recognized the following five provinces along the continental coast of the sea: South Korea, East Korea, South Primorye (including a large portion of the North Korean coast), North Primorye, and Northern Japan Sea. However, pelagic and benthic zonations may not coincide, and biogeographical boundaries are not frontier lines but transitional zones between different faunas.

We have demonstrated above that there is a transitional belt marking the decline of cold-water bivalve mollusks and a significant increase of warm-water species between Gangwon and Gyeongnam. A remarkable feature of the Ulsan Bay fauna is the presence of tropical-subtropical species not found in Yeongil Bay (Gyeongbuk) but common in the tidal flats and shallow waters of the Yellow Sea and the southern part of Korea; also, the occurrence of upwelling cold waters in summer does not prevent warm-water mollusks from living in Ulsan Bay (Lutaenko, 2014). It seems that the area between Yeongil and Ulsan bays is an important intermediate zone where the two faunas meet, but a wider transition zone should lie between Yeongil Bay and Busan (Lutaenko and Noseworthy, 2014), or even between Gangwon and Busan on the continental coast of the East Sea as there are some boreal-arctic species penetrating to Busan, and many tropical-subtropical species occur in Gyeongbuk (32 species), and even in Gangwon (22 species). Similarly, there is a corresponding zone between the Noto Peninsula and Tsugaru Strait in the eastern part of the sea, or the earlier "discontinuity belt" of abrupt change in the number of southern elements of Nishimura (1965). We believe that the area along the transition zone "Yeongil Bay-Busan" belongs to the large Sino-Japanese Province and is a part of the tropical Indo-Pacific fauna, whereas the boreal Japanese-Manchurian Province occupies the northern half of the East Sea.

\section{CONCLUSION}

1. In all, 316 species of Bivalvia are known currently for the East Sea coast of South Korea (Gyeongnam, Gyeongbuk and Gangwon), including insular regions of Korea, namely Dok-do (Liancourt Rocks) and Ullung-do (Dagelet Island), lying far away from the continent, and also species identified to genus level. Excluding the latter two groups, the total species richness of the continental Korean bivalve fauna is 304.

2. Along the South Korean coast, from north to south, species richness of bivalves increases: Gangwon, 143 species $\rightarrow$ Gyeongbuk, $131 \rightarrow$ Gyeongnam, 183. Comparison of the bivalve molluscan fauna of South Korea with neighboring areas shows that the fauna is quite rich, and is comparable with that of the East China Sea, which has 337 species. In all of South Korea, 449 species are known, whereas the faunas of China and Japan are richer - 1104 and 1472 species, respectively.

3. The Gyeongnam bivalve fauna has the highest number of "endemic" species (confined to a specific province and not found in other provinces along the eastern coast of Korea), 84, which constitute nearly half of the province's species list $(46 \%)$, or $28 \%$ of 
the total eastern South Korean fauna. The representatives of six truly tropical families, Pteriidae, Pinnidae, Dimyidae, Glauconomidae, Glossidae, Mesodesmatidae, and 26 tropical genera belonging to 13 families are recorded only from Gyeongnam. In Gyeongbuk, only $20 \%$ of the total provincial fauna are "endemic" which makes up only $8.5 \%$ of the total Korean East Sea fauna. The Gangwon fauna has a rather high proportion of species found only in this province, and are not known to the south, 57, or $40 \%$ of the total provincial fauna. However, in contrast to Gyeongnam, "endemics" in Gangwon are predominantly boreal species, widely distributed boreal, circumboreal and lowboreal, with an admixture of some warm-water mollusks.

4. A zonal-geographical analysis of the entire South Korean East Sea bivalve fauna shows that the great majority are warm-water mollusks, $77 \%$ (subtropical, 37\%, tropical-subtropical, 30\%, subtropical-boreal, $10 \%$ ), and the number of boreal (low-boreal, widely distributed boreal and circumboreal) species is lower, 19\%, whereas boreal-arctic mollusks have only $4 \%$. This demonstrates that the bivalve molluscan fauna of the eastern coast of Korea is subtropical, and has more affinities to the fauna of the East China Sea than to the northern East Sea.

5. Separate analysis of zonal-geographical compositions by provinces demonstrates a well-manifested trend of the increasing proportion of warm-water mollusks from north to south: while tropical-subtropical and subtropical species constitute $47 \%$ (68 species) in Gangwon, their dominance increases to $71 \%$ (93 species) in Gyeongbuk, and to 80\% (148 species) in Gyeongnam. However, the relative proportion and number of subtropical-lowboreal species remain about the same along the coast: Gangwon, 20 species (14\%) $\rightarrow$ Gyeongbuk, 18 (14\%) $\rightarrow$ Gyeongnam, 19 (10\%). The species richness of truly boreal (lowboreal, widely distributed boreal and circumboreal) bivalves shows a clear gradient too from north to south along the continental coast of the East Sea of Korea: Gangwon, 43 species (30\%) $\rightarrow$ Gyeongbuk, $17(13 \%) \rightarrow$ Gyeongnam, $13(8 \%)$. An abrupt four-fold change demonstrates that boreal-arctic mollusks are represented by $12(9 \%)$ species in Gangwon, and only by three species in each of the southern provinces (2\%).

6. The area between Yeongil and Ulsan bays is an important intermediate zone where the two faunas meet, but a transitional biogeographic zone lies broadly between Yeongil Bay and Busan, or even between Gangwon and Busan on the continental coast of the East Sea, as there are some boreal-arctic species penetrating to Busan, and many tropical-subtropical species occurring in Gyeongbuk and Gangwon. The area along the zone "Yeongil Bay-Busan" belongs to the large Sino-Japanese Province and is a part of the tropical Indo-Pacific fauna, whereas the boreal Japanese-Manchurian Province occupies the northern half of the East Sea.

\section{ACKNOWLEDGEMENTS}

We are grateful to Mrs. Irina E. Volvenko (Zoological Museum, Far East Federal University, Vladivostok) for graphic work and illustrations.

\section{REFERENCES}

Amano K. (2005) Migration and adaptation of late Cenozoic cold-water molluscs in the North Pacific. In: Migrations of Organisms. Climate, Geography, Ecology (ed. by Eleva, A.M.T.). Springer, Berlin, Heidelberg. P. 127-150.

Briggs, J.C. (1974) Marine Zoogeography. 475 pp. McGraw-Hill Book Co., New York, etc.

Golikov, A.N. and Scarlato, O.A. (1967) Molluscs of the Possjet Bay (the Sea of Japan) and their ecology. Proceedings of the Zoological Institute, USSR Academy of Sciences, 42: 5-154. [in Russian].

Hall, C.A. (1964) Shallow-water marine climates and molluscan provinces. Ecology, 45: 226-234.

Higo, S., Callomon, P. and Goto, Y. (1999) Catalogue and Bibliography of the Marine Shell-bearing Mollusca of Japan. 749 pp. Elle Scientific Publications, Osaka.

Honma, Y. and Kitami, T. (1978) Fauna and flora in the waters adjacent to the Sado Marine Biological Station, Niigata University. Annual Report of the Sado Marine Biological Station, Niigata University, 8: 7-81.

Honma, Y. and Kitami, T. (1979) Fauna and flora in the waters adjacent to the Sado Marine Biological 
Station, Niigata University: supplement 1. Annual Report of the Sado Marine Biological Station, Niigata University, 9: 27-36.

Honma, Y. and Kitami, T. (1995) Fauna and flora in the waters adjacent to the Sado Marine Biological Station, Niigata University; supplement 2. Annual Report of the Sado Marine Biological Station, Niigata University, 25: 13-30.

Ito, K. (1990) Distribution of molluscan shells in Wakasa Bay, Japan Sea. Bulletin of the Japan Sea National Fisheries Research Institute, 40: 79-211. [in Japanese with English abstract].

Ito, K., Matano, Y., Yamada, Y., and Igarashi, S. (1986) Shell species caught [by] S/S Rokko-Maru off the coast [of] Ishikawa Prefecture. Bulletin of the Ishikawa Prefectural Fisheries Experimental Station, 4: 1-179. [in Japanese with English abstract].

Kafanov, A.I. (1991) Bivalve Molluscs and Faunistic Biogeography of the Northern Pacific. 195 pp. Far East Branch, USSR Academy of Sciences, Vladivostok. [in Russian with English abstract].

Kafanov, A.I., Volvenko, I.V., Fedorov, V.V. and Pitruk, D.L. (2000) Ichthyofaunistic biogeography of the Japan (East) Sea. Journal of Biogeography, 27: 915-933.

Kolpakov, E.V. and Kolpakov, N.V. (2004) Distribution and growth of bivalve mollusc Mercenaria stimpsoni in Inokov Bay (north Primorye). Izvestiya TINRO, 136: 197-204. [in Russian with English abstract].

Kuroda, T. (1957) A catalogue of molluscan shells of Sado Island, Sea of Japan. Transactions of the Sado Natural History Society, 1: 13-32. [in Japanese].

Kussakin, O.G. (1990) Biogeography of isopod crustaceans in the boreal Pacific. Bulletin of Marine Science, 46: 620-639.

Kwon, Y.W. and Lee, J.D. (Eds.). (2010) The Geography of Korea. 432 pp. National Geographic Information Institute (NGII), Suwon.

Lee, J.-S. and Min, D.-K. (2002) A catalogue of molluscan fauna in Korea. Korean Journal of Malacology, 18: 93-217. [in Korean with English abstract].

Lutaenko, K.A. (2006) Bivalve mollusks of Ussuriysky Bay (Sea of Japan). Part 2. Bulletin of the Russian Far East Malacological Society, 10: 46-66.

Lutaenko, K.A. (2010) Bivalve molluscan biogeography of the Japan Sea: an overview. In: Proceedings of China-Russia Bilateral Symposium on "Comparison on Marine Biodiversity in the Northwest Pacific Ocean”, 10-11 October 2010, Qingdao, China. IOCAS, Qingdao. P. 1-6.

Lutaenko, K.A. (2012) Zonal-biogeographical analysis of bivalve molluscan faunas in three major areas of the western Sea of Japan. In: Proceedings of the Russia-China Bilateral Symposium on Marine Ecosystems under the Global Change in the Northwestern Pacific, Vladivostok, Russia, October 8-9, 2012 (ed. by Lutaenko, K.A.). Dalnauka, Vladivostok. P. 89-94.
Lutaenko, K.A. (2014) Bivalve mollusks in Ulsan Bay (Korea). Korean Journal of Malacology, 30: 57-77.

Lutaenko, K.A., Je, J.-G. and Shin, S.-H. (2006) Bivalve mollusks in Yeongil Bay, Korea. 2. Faunal analysis. Korean Journal of Malacology, 22: 63-86.

Lutaenko, K.A. and Noseworthy, R.G. (2012) Catalogue of the Living Bivalvia of the Continental Coast of the Sea of Japan (East Sea). 247 pp. Dalnauka, Vladivostok.

Lutaenko, K.A. and Noseworthy, R.G. (2014) Biodiversity and biogeographical patterns of bivalve mollusks in the Sea of Japan. In: Marine Biodiversity and Ecosystem Dynamics of the North-Western Pacific Ocean (ed. by Sun, S., Adrianov, A.V., Lutaenko, K.A., Sun X. Science Press, Beijing. P. 160-188.

Lutaenko, K.A. and Pretsiniek, I.P. (2014) On the bivalve molluscan fauna of North Hamgyong Province (North Korea). Bulletin of the Russian Far East Malacological Society, 18: 63-78. [in Russian with English abstract].

Min, D.-K., Lee, J.-S., Koh, D.-B. and Je, J.-G. (2004) Mollusks in Korea. 566 pp. Min Molluscan Research Institute, Seoul. [in Korean].

Nishimura, S. (1965) The zoogeographical aspects of the Japan Sea. Part I. Publications of the Seto Marine Biological Laboratory, 13: 35-79.

Noseworthy, R.G., Lim, N.-R. and Choi, K.-S. (2007) Catalogue of the mollusks of Jeju Island, South Korea. Korean Journal of Malacology, 23: 65-104.

Rex, M.A., Crame, J.A., Stuart, C.T. and Clarke, A. (2005) Large-scale biogeographic patterns in marine mollusks: a confluence of history and productivity? Ecology, 86: 2288-2297.

Rho, B.J., Choe, B.L., Song, J.-I., Park, K.S., Lee, I.-S. and Park, J.-K. (1997) An analysis of invertebrate community at the tidal and subtidal zone in Onsan Bay with regard to the effect of pollution. Korean Journal of Environmental Biology, 15: 79-88. [in Korean with English abstract].

Ryu, S.-H., Jang, K.-H., Choi, E.-H., Kim, S.-K., Song, S.-J., Cho, H.-J., Ryu, J.-S., Kim, Y.-M., Sagong, J., Lee, J.-H., Yeo, M.-Y., Bahn, S.-Y., Kim, H.-M., Lee, G.-S., Lee, D.-H., Choo, Y.-S., Pak, J.-H., Park, J.-S., Ryu, J.-S., Khim, J.-S. and Hwang, U.-W. (2012) Biodiversity of marine invertebrates on rocky shores of Dokdo, Korea. Zoological Studies, 51(5): 710-726.

Scarlato, O.A. (1981) Bivalve mollusks of temperate latitudes of the western portion of the Pacific Ocean. Guide-Books on the Fauna of the USSR Published by the Zoological Institute, USSR Academy of Sciences, 126: 1-479. [In Russian].

Sedova, L.G. and Sokolenko, D.A. (2008) Stock and distribution of the scallop Mizuhopecten yessoensis in the southwestern part of Peter the Great Bay. Izvestiya TINRO, 155: 76-87. [in Russian with English abstract].

Sedova, L.G., Sokolenko, D.A., Borisovets, E.E., Afeichuk, L.S. and Bratishchev, V.S. (2007) Resources of 
commercial bivalve molluscs in Peter the Great Bay. Trudy VNIRO, 147: 320-334. [in Russian].

Willig, M.R., Kaufman, D.M. and Stevens, R.D. (2003) Latitudinal gradients of biodiversity: pattern, process, scale, and synthesis. Annual Review of Ecology, Evolution, and Systematics, 34: 273-309.

Xu, F. (1997) Bivalve Mollusca of China Seas. 333 pp. Science Press, Beijing. [in Chinese].

$\mathrm{Xu}$, F. and Zhang, J. (2011) Characteristics of bivalve diversity in typical habitats of China seas.
Biodiversity Science, 19(6): 716-722. [in Chinese with English abstract].

Yi, S.K., Hong, J.-S., and Lee, J.H. (1982) A study on the subtidal benthic community in Ulsan Bay, Korea. Bulletin of Korea Ocean Research and Development Institute, 4: 17-26.

Yoo, S.K. and Park, K.Y. (1979) Distribution of drifting larvae of scallop, Patinopecten yessoensis, in the Yeong-il Bay. Journal of the Oceanological Society of Korea, 14: 54-60. 